\title{
Contents, Vol. 82, 1989
}

No. 1

Original Paper

Deficiency of Lymphocyte Lectin-Dependent Cytotoxicity in Myelodysplastic Syndromes

Fontana, L.; De Sanctis, G.; De Rossi, G.; Bottari, V.; Petti,

M.C.; Ensoli, F.; Pasqualetti, D.; Mandelli, F

Marrow Transplantation for Children with Acute Leukemia: Experience of Pesaro

Giardini, C.; Polchi, P.; Lucarelli, G.; Galimberti, M.;

Angelucci, E.; Baronciani, D.; Durazzi, S.M.T.; Manenti,

F.; Politi, P.; Moretti, L 7

Prognostic Evaluation of Initial Bone Marrow Histopatholog-

ical Features in Chronic Granulocytic Leukemia

Cervantes, F.; Rozman, C; Feliu, E 12

Effect of Hydrocortisone on BFU-E Growth and on Burst-

Promoting Activity of T Lymphocytes in Man

Morra, L.; Ponassi, A.; Moccia, F.; Mela, G.S.; Ponassi, L;

Bessone, G 16

Relationship between Lymphocyte Size and Enzyme Activities in Two Morphological Variants of

B-Chronic Lymphocytic Leukaemia

Vives Corrons, J.L.; Colomer, D.; Pujades, A.; Matutes, E.;

Pastor, C; Aymerich, M 22

Human Red Blood Cell Loading with Hexokinase-Inactivating Antibodies. An in vitro Model for

Enzyme Deficiencies Magnani, M.; Rossi, L.; Bianchi, M.; Serafini, G.; Stocchi, V. 27

Bone Marrow Stromal Cells in Myeloproliferative Disorders

Hirata, J.; Takahira, H.; Kaneko, S.; Nishimura, J.; Nawa-

ta, $\mathrm{H} \quad 35$

Case Reports

Amodiaquine-Induced Agranulocytosis: Report of a Case with in vitro Studies of Granulocyte-

Macrophage Progenitor Cells

Aymard, J.P.; Rouveix, B.; Ferry, R.; Janot, C; May, T.;

Legras, B.; Streiff, F 40

Successful Splenectomy in May-Hegglin Anomaly: Report of a

Case with Platelet Kinetic Studies

Raveh, D.; Krausz, Y.; Eldor, A 43

Aplastic Crisis due to Human B19 Parvovirus Infection in Red

Cell Pyrimidine-5' -Nucleotidase Deficiency

Rechavi, G.; Vonsover, A.; Manor, Y.; Mileguir, F.; Shpil-

berg, O.; Kende, G.; Brok-Simoni, F.; Mandel, M.; Gotlieb-

Stematski, T.; Ben-Bassat, L; Ramot, B 46

Thrombosis Associated with Procainamide-Induced Lupus

Anticoagulant

List, A.F.; Doll, D.C 50

Correspondence 
A Modification of the 'Pink Test' May Improve the Diagnosis of Hereditary Spherocytosis Pinto, L.; Iolascon, A.; Miraglia del Giudice, E.; Nobili, B. 53

Book Reviews $\quad 55$

No. 2

Original Paper

Thalassemic Patients Are at High Risk for Transfusion-Transmitted Cytomegalovirus Infections Germenis, A.; Politis, C 57

Hyperglycemia-Conditioned Increase in Alpha-2-Macroglobu-

lin in Healthy Normal Subjects: A Phenomenon Correlated with Deficient Antithrombin III Activity

Ceriello, A.; Quatraro, A.; Dello Russo, P.; Marchi, E.; Bar-

banti, M.; Giugliano, D 61

Arrangements of $\alpha$-Globin Gene Cluster in Taiwan

Peng, H.-W.; Choo, K.-B.; Ho, C.-H.; Yen, M.-S.; Liung,

W.-Y.; Lin, C.-K.; Yang, Z.-L.; Ng, H.-T.; Ching, K.-N.;

Han, S.-H 64

Pyrimidine 5-Nucleotidase Acquired Deficiency in B-Thalas-

semia: Involvement of Enzyme-SH Groups in the Inactiva-

tion Process

David, O.; Vota, M.G.; Piga, A.; Ramenghi, U.; Bosia, A.;

Pescarmona, G.P

Localization of Granular Components in ADP- and/or Teleo-

cidin-Stimulated Human Blood Platelets as Revealed by

Immunocytochemical Methods

Kawakami, H.; Higashihara, M.; Kume, S.; Yamanaka, M.;

Hirano, $\mathrm{H} \quad 75$

Decreased C-Peptide Secretion in Sickle Cell Anemia

Saad, S.T.O.; Braga, G.S.; Saad, M.J.A 81

Case Reports

Calla-Positive Acute Leukaemia with $\mathrm{t}(5 \mathrm{q} ; 14 \mathrm{q})$ Translocation

and Hypereosinophilia - A Unique Entity?

Baumgarten, E.; Wegner, R.D.; Fengler, R.; Ludwig, W.D.;

Schulte-Overberg, U.; Domeyer, C; Schüürmann, J.;

Henze, G 85

Phagocytic Multiple Myeloma with Disseminated Intravascu-

lar Coagulation

Matsuzaki, H.; Hata, H.; Watanabe, T.; Takeya, M.; Takat-

suki, K 91

Contents

111

Primary Plasma Cell Leukemia: A Case Report of Successful

Responder to a Combination Chemotherapy of Vincris-

tine, Doxorubicin and Dexamethasone

Suzuki, M.; Kawauchi, K.; Sugiyama, H.; Yasuyama, M.;

Watanabe, $\mathrm{H} \quad 95$

Treatment of Pure Red Cell Aplasia that Is Resistant to Conventional Immunosuppressive Therapy with Intermittent

Administration of Methotrexate

Sato, N.; Takatani, O.; Hosoi, T.; Shirafuji, N,; Urabe, A.; 
Takaku, F 98

Acute Erythroblastic Leukemia. Cytological, Cytogenetic and Phenotypic Studies in One Case

Soler, J.; Pujol-Moix, N.; Bosch, M.A.; Guanyabens, C;

Aventin, A.; Boque, C; Brunet, S 102

Correspondence

Intravenous Immunoglobulins as Pre-Operative Management

in a Case of Hereditary Spherocytosis

Olivieri, O.; Capra, F.; Girelli, D.; Corrocher, R.; De

Sandre, G 106

About Leukocyte Alkaline Phosphatase

Özsoylu, S 108

Intravenous Methylprednisolone for Myelofibrosis

Özsoylu, S 109

Immunoglobulin and T-Cell Receptor Gene Rearrangements

in Hodgkin's Disease

Daus, H.; Schwarze, G.; Kümel, G.; Scheurlen, P.G. ... 110

Book Reviews $\quad 112$

Infection of Hematopoietic and Stromal Cells in Human Con

tinuous Bone Marrow Cultures by a Retroviral Vector

Containing the Neomycin Resistance Gene

Holland, C.A.; Rothstein, L.; Sakakeeny, M.A.; Anklesaria,

P.; Griffin, J.D.; Harigaya, K.; Newburger, P.E.; Green-

berger, J.S 136

Case Reports

Dapsone-Induced Haemolytic Anaemia and Agranulocytosis

in a Patient with Normal Glucose-6-Phosphate-Dehydro-

genase Activity

Figueiredo, M.S.; Pinto, B.O.; Zago, M.A 144

Translocation $\mathrm{t}(1 ; 3)(\mathrm{p} 36 ; \mathrm{q} 21)$ in Sideroblastic Anaemia

Fukuoka, T.; Kameoka, H.; Yasukawa, M.; Yanagisawa, K.;

Tamai, T.; Fujita, S 146

Myelofibrosis with Myeloid Metaplasia following Essential

Thrombocythaemia

Liberato, N.L.; Barosi, G.; Costa, A.; D’Elia, P.; Boccaccio, P. 150 Recurrent Thrombophlebitis

Due to Protein C Deficiency

after Splenectomy for Immune Thrombocytopenic Pur-

pura

Lugassy, G.; Klepfish, A.; Berrebi, A154

Chronic Neutrophilic Leukemia with Dysplastic Features. A

New Variant of the Myelodysplastic Syndromes?

Zoumbos, N.C.; Symeonidis, A.; Kourakli-Symeonidis, A. 156 Myelodysplastic Syndrome

Preceding Acute Myelomonocytic

Leukemia with Dysplastic Marrow Eosinophilia and

$\operatorname{Inv}(16)$

Horiike, S.; Misawa, S.; Nishida, K.; Nishigaki, H.; Tsuda,

S.; Taniwaki, M.; Takino, T.; Abe, T 161

Gelatinous Transformation of the Bone Marrow: Manifestation of an Acute Leukemia?

Ifrah, N.; Saint-Andre, J.-P.; Gentile, L. de; Foussard, C;

Chevailler, A.; Flandrin, G.; Boasson, M 165 
No. 3

Original Paper

Effect of Desferrioxamine B on Hemolysis in Glucose-6-Phos-phate Dehydrogenase Deficiency

Khalifa, A.S.; El-Alfy, M.S.; Mokhtar, G.; Fakeir, A.A.;

Khazbak, M.A.; El-Baz, F.; El-Kholy, M 113

Acute Promyelocytic Leukemia: A 5-Year Experience with New Antileukemic Agents and a New Approach to Preventing Fatal Hemorrhage

Feldman, E.J.; Arlin, Z.A.; Ahmed, T.; Mittelman, A.; Ascensao, J.L.; Puccio, C.A.; Coombe, N.; Baskind, P. . . 117

Multiple Myeloma: Beta-2-Microglobulin is not a Useful Fol-low-Up Parameter

Boccadoro, M.; Omedè, P.; Frieri, R.; Battaglio, S.; Gal-

lone, G.; Massaia, M.; Redoglia, V.; Pileri, A 122

Investigations on $ß$-Glucuronidase-Positive Erythrocytic In

clusions

Budde, R.; Schaefer, H.-E 126

In vitro Effects of Phorbol and Phorbol Ester on the Prolifera

tion and Enzyme Activities of Bone Marrow Stromal Cells

in Rats

Miszta, $\mathrm{H} \quad 131$

No. 4

Review

Vitamin $\mathrm{B} \prod$ and Geriatrics: Unanswered Questions

Thompson, W.G.; Freedman, M.L 169

Clinical Review

Implications of 'Cell Kill' for the Treatment of Acute Myelog-enous Leukemia: Can the Cure

Rate Be Increased? Arlin, Z.A.; Hagenbeek, A.; Feldman, E.J.; Andreeff, M. . 175

Original Paper

Free-from-Failure Survival in Hodgkin's Disease. Long Term Analysis of 148 Cases Treated with a MOPP-Modified Protocol

Silingardi, V.; Federico, M.; Frassoldati, A.; Barbieri, F.;

Palomba, G.; Mauri, C 179

IV

Contents

T-Cell Colony Formation in Healthy Homosexual Men with out Anti-Human Immunodeficiency Virus Antibody

Wakabayashi, Y.; Sugimoto, M.; Ishiyama, T.; Hashimoto, M.; Horie, S.; Hirose, S 187

Immunophenotypic Demonstration of Two Natural Killer Surface Markers, H25 and H366, on Fresh Human Leu-kemic Cells (With 1 color plate)

Körfer, A.; Kirchner, H.; Schneekloth, C; Bührer, C; Wis-

niewski, D.; Gulati, S.; Clarkson, B.; Knowles, R.; Poliwoda,

H.; Atzpodien, J 193

Case Reports

Hemophagocytic Syndrome Causing Complete Bone Marrow

Failure. Report of an Extreme Case of a Reactive Histio-

cytic Disorder

de la Serna, F.J.; Lopez, J.I.; Garcia-Marcilla, A.; Ortiz-

Conde, M.C.; Mestre, M.J 197

Thrombotic Thrombocytopenic Purpura: Report of a Case 
with a Possible Response to High-Dose Intravenous

Gamma Globulin

Staszewski, H.; Colbourn, D.; Donovan, V.; Ludman, H.. 201

Clonal Evolution in Ph-Negative, bcr-Positive Chronic My-eloid Leukaemia before and after Bone Marrow Transplantation

Seeker-Walker, L.M.; Cooke, H.M.; Browett, P.J.; Norton,

J.D.; Kitchen, C; Prentice, A.G.; Prentice, H.G 205

Acute Nonlymphocytic Leukemia: Evidence of Clonogenic

Cells in Peripheral Blood in Early Complete Remission

Castagnola, C; Bonfichi, M.; Colombo, A.; Bernasconi, P.;

Bernasconi, C 210

Correspondence

A New Modification of the 'Pink Test' for the Diagnosis of Hereditary Spherocytosis

Sureda Balari, A.; Villarrubia Espinosa, J.; Fernandez

Fuertes, $1 \quad 213$

Book Review 215

Announcement

Author Index $\quad 217$

Subject Index 219

S. Karger - Medical and Scientific Publishers

Basel · München · Paris · London · New York · New Delhi · Bangkok · Singapore • Tokyo ·

Sydney

Drug Dosage

The authors and the publisher have exerted every effort to ensure that drug selection and dosage set forth in this text are in accord with current recommendations and practice at the time of publication. However, in view of ongoing research, changes in government regulations, and the constant flow of information relating to drug therapy and drug reactions, the reader is urged to check the package insert for each drug for any change in indications and dosage and for added warnings and precautions. This is particularly important when the recommended agent is a new and/or infrequently employed drug.

All rights reserved.

No part of this publication may be translated into other languages, reproduced or utilized in any form or by any means, electronic or mechanical, including photocopying, recording, microcopying, or by any information storage and retrieval system, without permission in writing from the publisher or, in the case of photocopying, direct payment of a specified fee to the Copyright Clearance Center (see 'Information for Readers and Subscribers').

(C) Copyright 1989 by S. Karger AG, P.O. Box, CH-4009 Basel (Switzerland) Printed in Switzerland by Buchdruckerei Basler Zeitung, Basel 